Nanna Kann-Rasmussen, lektor, Institut for Informationsstudier, Københavns Universitet, nanna.kann.rasmussen@hum.ku.dk

Pia Quist, lektor, Institut for Nordiske Studier og Sprogvidenskab, Københavns Universitet, pqj@hum.ku.dk Kristin Veel, lektor, Institut for Kunst og Kulturvidenskaber, Københavns Universitet, kristinv@hum.ku.dk

\title{
Efter SKAM
}

\section{Kollektive perspektiver på den individuelle oplevelse}

\begin{abstract}
Introduktion
I værket Take Care of Yourself fra 2007 sender den franske kunstner Sophie Calle et afskedsbrev fra en tidligere elsker til 107 forskellige kvinder for at de med afsæt i deres profession kan hjælpe hende med at afkode og fortolke brevet. Sprogforskeren, detektiven, balletdansen, grafikeren, advokaten har selvsagt alle forskellige tilgange og perspektiver på brevets tekst. I efteråret 2016 fandt vi, som tre humanistiske akademikere midt i livet, os opslugt af en teenage-forelskelse foranlediget af netdrama-serien SKAM, som ligeledes krævede bearbejdelse. Dette temanummer er vores "taking care of ourselves". Det er et katalog med femten forskellige vinkler på serien fra mindst lige så mange faglige og teoretiske ståsteder - herunder sprogvidenskabelige, juridiske, kulturpolitiske, queer teoretiske, urbanitetsteoretiske, medievidenskabelige, kulturteoretiske og musikvidenskabelige perspektiver. Her bliver vi klogere på en række videnskabelige tilgange, som det er muligt at anlægge på serien, og det bliver tydeligt, hvor mange fagdiscipliner serien har talt ind i.
\end{abstract}

Siden ideen om temanummeret blev sat i søen, har serien nået sin endelige afslutning med fjerde sæson, og det kræver, at vi ikke bare forholder os til den "her-og-nu-oplevelse", vi har haft, mens serien kørte, men også seriens efterliv. Hvordan bevares en serie som denne for eftertiden? Hvordan formidles første generations seeres oplevelse? Og hvordan vil den opleves af fremtidige generationer? Dette temanummer giver dels et indblik i, hvordan bidragsyderne oplevede serien, mens den kørte første gang, og hvordan de genkender deres respektive forskningsfelter i serien, dels begynder det at stille metodiske spørgsmål til, hvordan vi nu - efter seriens afslutning - kan forholde os retrospektivt til dette mange-facetterede fænomen. Som Calles kærlighedsforhold er det vi har levet med og $i$ slut, og det burde på den ene side give en større distance og klarsyn. På den anden side konfronteres vi med det, som har været performancekunstens vilkår i mange år: hvordan forholde sig til noget som i dén grad har en så markant situeret og tidslig komponent? Og hvor interaktionen med publikum på tværs af medieplatforme har været et afgørende element i den samlede oplevelse?

Men for kort at opsummere, hvad er så objektet for denne tværdisplinære unders $\varnothing$ gelse? Hvad er - eller var SKAM? Og hvad er det SKAM har skabt? Og gjort ved alle dens mange fans og følgere?

SKAM er produceret af den norske public service-station NRK. Den blev sendt på NRK P3's hjemmeside med korte klip publiceret lørdag til fredag, hvorefter klippene blev samlet til en hel episode. Det første SKAM-klip blev lagt på hjemmesiden mandag den 22. september 2015, og det sidste I $\emptyset$ rdag den 24. juni 2017. I den mellemliggende periode publiceredes fire sæsoner med henholdsvis 11, 12, 10 og 10 episoder. Første sæson blev fra begyndelsen 
en stor succes i Norge med det højeste antal streamede episoder nogensinde, mens det først var med sæson to og især tre at serien for alvor brød igennem i resten af Skandinavien. Endnu i skrivende stund er SKAM det mest streamede program på Danmarks Radios hjemmeside nogensinde. SKAM's enorme popularitet betød, at der skød fanfællesskaber op, ikke bare i de nordiske lande, men i hele verden. I Danmark har det især været facebookgruppen Kosegruppa DK der har dannet platform for det store fan-engagement, som serien har bragt med sig. Det er dog ikke kun blandt lægmands-seere, at serien har imponeret. Således kom det frem under en paneldebat om SKAM på Schæffergården, arrangeret af Fondet for Dansk-Norsk samarbejde, at flere inden for tv-branchen opfatter serien som så banebrydende, at man taler om et ' $f \varnothing r$ ' og et 'efter' SKAM. Seriens gennemførte integration af sociale medieplatforme som fortælleteknisk drive har formentlig haft den konsekvens, at det i dag ikke er muligt at skabe nye tv-serier uden, at producenterne må tage stilling til i hvilken udstrækning sociale medier skal være en del af produktionen.

I denne introduktion forsøger vi, ud over at præsentere de 14 artikler, at samle det tværvidenskabelige multiperspektiv, som tidsskriftet som helhed kaster på SKAM, i tre forskellige linser: de tematikker den tager op, de formmæssige virkemidler den benytter sig af, samt den reception og fankultur den har givet anledning til og som både arbejder inden for og overskrider de institutionelle rammer, som serien er vokset ud af. Disse tre linser er nødvendigvis dybt sammenvævede, men vi bruger dem her som en matrix i forhold til at organisere bidragene i dette temanummer af NTIK, samtidig med at vi på baggrund af bidragenes analyser argumenterer for, at SKAM konfigurerer et forhold mellem et jeg og et vi på både et tematisk, formmæssigt og receptionsmæssigt niveau, som har været afgørende for seriens success. Det er netop denne gennemgående vekselvirkning mellem det individuelle og det kollektive perspektiv i serien på alle niveauer, som nødvendiggør den tværvidenskabelige tilgang. Artiklerne i dette nummer bidrager med hver deres dimension til forståelsen af SKAM, men som samlet fænomen kræver den et tværvidenskabeligt perspektiv. "Mennesker trenger mennesker", skriver William i sæson 2, og vi kan tilføje, at forskere trenger andre forskere for at kunne begynde det teoretiske og metodemæssige arbejde med at forstå et fænomen og et stykke mediemæssig samtidshistorie som SKAM.

\section{De tematiske perspektiver. Forestillinger om identiteter mellem SKAM og skyld}

Ifølge medieforsker Glen Creeber er et definerende træk ved de populære nordiske tv-dramaer, der har fået prædikatet Nordic noir, at individet til stadighed relateres til et kollektiv, der dels skaber og rammesætter individet, og dels påvirkes af individets handlinger (Creeber 2015). Personernes liv og handlinger i f.eks. Broen og Forbrydelsen viser sig ofte at være forbundne på implicitte og overraskende måder, indimellem med fatale konsekvenser. Det skaber ifølge Creeber et billede af et samfund der er "made up of millions of individuals that are all intimately connected, a world where a single action can cause a never-ending series of ripples across a whole community" $(2015,24)$. Creeber argumenterer videre for, at skildringen af denne 'interdependens' mellem kollektiv og individ "offers its audience a subtle moral message, one that urges them to believe in the redemptive power of love and community" (Creeber 2015, 27). Hvis vi følger Creeber i sin karakteristik af Nordic noir og ser på individ og kollektiv i SKAM, er det tydeligt, at SKAM lægger sig i sporet heraf. Den fælles forbundethed mellem kollektiv og individ tager forskellige former, men løber som en rød tråd gennem alle fire sæsoner (KannRasmussen et al, forthcoming.). Mest markant - og dramatisk - bliver det måske i sæson 4, hvor Sanas falske konto på instagram utilsigtet rammer Vilde og nær får Isak smidt ud af skolen. Sana kæmper for en ligeværdig plads blandt sine jævnaldrende, men kampen synes i flere tilfælde ulige, og som seer følger og forstår man de hændelser, der fører frem til hendes (moralsk anstødelige) handlinger, og derpå hvordan de får konsekvenser for hende selv - for hvordan hun bliver set og hvordan hun ser sig selv. Individets position, eller rettere individets tilbliven i det kollektive, kommer i SKAM på mange måder til at fremstå som netop en kamp, eller i hvert fald et 'arbejde', som den enkelte hele tiden er i gang med. Og det er netop dette arbejde med at være/at få lov til at være et individ i kollektivet, der tematiseres gennem begrebet 'SKAM'.

Christa Lykke Christensen citerer Skårderud for at definere SKAM som repræsenterende en "selviagttagelse". Skamfølelsen er knyttet til "selve forholdet mennesker imellem, og til hvordan andre opleves at vurdere én selv". Christensen stiller i sit bidrag spørgsmålet om titlen på SKAM betyder, at serien så behandler skam som en negativ følelse og som socialt virksom mekanisme. For at besvare dette gør hun teoretisk rede for forskellen på 
skyld og skam og bruger sociologen Erving Goffmans teori om facework til at vise, hvordan skammen spiller med når f.eks. Vilde fors $\varnothing$ ger at opretholde og bekræfte det selvbillede hun gerne vil have af sig selv. Christensen argumenterer endvidere for at selv uhæmmet og ukontrolleret adfærd, som det f.eks. fremstilles i de allerførste scener i både sæson 1 og 2, hvor der vises klip fra vilde fester med unge, der drikker, danser og har sex, kan tolkes som en måde for de unge at leve op til tidens ideal om at realisere sig selv på. Festerne kan ses som et kollektivt rum for selvudfoldelse, hvor risiko for ansigtstab opleves som mindre. Hverdagens skam unders $\varnothing$ ges også i Elisabeth Oxfeldts artikel. Men hos Oxfeldt sættes det man kunne kalde den lokale hverdagsskam over for "global skyld". Med global skyld henviser Oxfeldt til den fornemmelse af skyld, som mange skandinavere kan have over at være materialistisk velstillede i en verden fuld af fattigdom. Skismaet mellem lokal hverdagsskam og global skyld undersøges gennem Nooras kamp for at finde sit ståsted i relationen til William. Noora og hendes relation til William kan ifølge Oxfeldts læsning på den måde ses som en allegori over en idealpolitik der tørner sammen med en skandinavisk realpolitik.

I sæson 3 følger vi Isaks kvaler og udvikling. Hos ham er SKAMmen tæt knyttet til sit begær til Even, og den bliver gennem sæsonens ti afsnit en udfordrende del af hans proces og kamp. I processen "fucker han op", som Mons Bissenbakker og Michael Nebeling formulerer det, og lige som Sana i sæson 4 bliver han og vi som seere klogere undervejs. Isaks læringsproces trækkes frem i Bissenbakker og Nebelings artikel om skrøbelighed og queeralliancer i SKAM: "Isak dummer sig konstant: Han sårer Eskild med homofobiske kommentarer, han fornærmer Sana med sine fordomme om religion, og han skubber Even væk med sine opfattelser af psykisk sygdom. Men det magiske er, at man som seer forstår ham og holder af ham alligevel". Bissenbakker og Nebeling fremhæver seriens tematisering af hverdagshomofobi og den "marginaliseringserfaring" som følger med. Men selvom Isak 'fucker op', bliver kollektivet ikke fritaget for ansvar for de subtile marginaliseringsprocesser. Kollektivets omsluttende heteronormativitet illustreres i scenen hvor Isak og hans venner overværer "dansechiksne". Mens de heteroseksuelle venner Mahdi, Jonas og Magnus henføres over pigernes dans og skønhed, ser man at Isaks oplevelse er en helt anden. Musikken til pigernes dans i slow motion er skiftet ud med klassisk musik, hvilket ifølge Bissenbakker og Nebelings læsning bliver til en skildring af livet som queer i et heteronormativt samfund: "Det er lige præcis mislyden mellem heteroseksualiteten og det begær, man forventes at have investeret i den, som genererer følelsen af at være ad led". Queer-erfaringen, at være 'ude af synk' med den virkelighed, der af kollektivet forventes man er en del af, behandles også af Lea Laura Michelsen $i$ en analyse af hvordan selve mediet bruges som middel til at skildre og eksperimentere med parallelle virkeligheder. Michelsen undersøger, hvordan karaktererne i SKAM bruger medier til at udfolde forskellige og forskudte erfaringsuniverser, idet hun inddrager begrebet queer-tid. Et medie skal i Michelsens sammenhæng forstås bredt som ramme for "væren og erkendelse". Således udgør vand og luft forskellige medier og med Isak og Evens første erotiske $m \varnothing d e$ placeret under vand i seriens centrale pool-scene illustreres, i Michelsens læsning, den fundamentalt anderledes eksistensbetingelse som drengenes kærlighed har. Queer-tiden i poolen udfordres af "hetero-tidens" altoverskyggende "her-og-nu, som Isak er fanget i og ude af synk med". Men mediets forskudte tid og rum udgør også et rum der gør queer-begæret mulig.

Et lignende mulighedsrum kan man muligvis også skimte i nogle af de fremstillinger som SKAM giver af byen Oslo. Oslo forstået som storby med storbyens mulige anonyme folder og lommer skildres - ofte i glimt og korte klip - som et rum for begærsudfoldelser. Med udgangspunkt i åbningsscenerne til hver af de fire sæsoner undersøger Svava Riesto og Henriette Steiner i deres bidrag, hvordan SKAM opererer med forskellige byforestillinger mellem tradition og fornyelse. Det første møde med byen i SKAM giver indtryk af, at de unge i serien er 'urbanister', der vurderer byen som et sted for frisættelse og selvudfoldelse. Men ser man nærmere efter, bygger serien også, ifølge Riesto og Steiner, på nedarvede kulturelle forestillinger om storbyen som fordærvende. Bag facaden præsenterer SKAM "storbyen som et sted fyldt av fristelser og forbruk; et kapitalistisk styrt emblem på global ulikhed".

\section{Formmæssige perspektiver og seriens virkemidler. Sprog, musik og medier}

Forskyder vi fokus fra selve fortællingen til det formmæssige og de virkemidler serien gør brug af, træder forhandlingen mellem det individuelle og det kollektive ligeledes frem som centralt. Som flere af vores bidrag 
peger på, er en række af seriens centrale formmæssige karakteristika med til at skabe den intense identifikation med SKAM-universet, som har medvirket til dens store popularitet. Det er ikke mindst gennem sin brug af sprog, musik og medier, at serien opnår sin særlige indlevede fortælleform, der rent formmæssigt peger på vekselvirkningen mellem på den ene side den indlevede intimitet og sammensmeltning med karaktererne, og på den anden side det fællesskab, som den kollektive oplevelse af at se og dele SKAM på sociale medier skaber. Det sætter en række af vores bidrag fokus på fra forskellige akademiske fagdiscipliner.

De to sprogforskere Pia Quist og Astrid Ravn Skovse behandler således i deres artikel, den rolle sproget i serien spiller for dens evne til at skabe indlevelse og en næsten dokumentaristisk fornemmelse af autenticitet hos seerne. De argumenterer for, at brugen af nutidigt ungdomsnorsk i filmscenerne såvel som i SKAM-figurernes chat- og SMS-beskeder er med til at fremstille et varieret persongalleri og underst $\varnothing$ tte oplevelsen af autenticitet og identifikation. Hver karakter bruger særlige individuelle lingvistiske karakteristika som identitetsmark $\emptyset$ rer, ligesom drenge- og pige-grupperne har forskellig sprogbrug, der bruges som inklusions- og eksklusionsmark ører. Men også 'uden om', i medier og faninteraktioner, har sprog vist sig at spille en central rolle, hvorfor Quist og Skovse gennemgår eksempler på, at sprogelementer fra SKAM diskuteres, deles og også kommercialiseres. Et andet eksempel på etableringen af fællesskaber og legen med kulturelle for-forståelser sætter Elise Ligaard fokus på fra et musikvidenskabeligt perspektiv i sin artikel om, hvordan musikken bruges i SKAM til at portrættere karaktererne. Hun udfolder i en række udvalgte scener den kulturhistoriske kontekst og illustrerer, hvordan specifikke musiknumres konnotationer og associationer bruges i serien til at skabe nuancerede karakterer, som både skaber genkendelse hos seerne, men også udfordrer etablerede forestillinger.

Også karakterernes medievaner bliver identitetsmarkører og bidrager til vores forståelse og indlevelse i deres liv, samtidig med at muligheden for at følge dem på sociale medier udvisker skillelinjen mellem de fiktive karakterer og de $\emptyset$ vrige venner vi følger online. Som nævnt opleves serien på tværs af en lang række forskellige medieplatforme såsom Instagram, Facebook og YouTube. Ligesom sproget og musikken bruges til at mime en urban ungdomsstil i samtids-Oslo, er også brugen af medier i serien central, hvilket Ruth Grüters og Knut Ove Eliassen kredser om i deres gennemgang af mediebrugen ud fra et medieøkologisk perspektiv. Samtidig med at de trækker den kulturhistoriske ramme op og påpeger slægtskabet med 1700-tallets brevromaner som Samuel Richardsons Clarissa, 1800-tallets avisføljetoner som Dickens' The Old Curiosity Shop og 1900-tallets radioteater som historiske eksempler på samtidsfiktion, der udforsker sin tids medier, argumenterer de for, at det som adskiller SKAM fra andre populære serier i dag, netop er den måde, som serien bruger vor tids medievirkelighed i form af de sociale medier til at mobilisere publikum og skabe en stærk indlevelse i fiktionsuniverset. I tråd hermed argumenterer Kristin Veel i sit bidrag fra et litteratur- og kulturteoretisk perspektiv - og ved hjælp af en række nedslag på seriens brug af henholdsvis gentagelsen, pausen og tidsoplevelsen - for at den fortælleform, som SKAM udvikler, kan forstås som en re-konfiguration af det narrative begær, der modsvarer det 21. århundredes digitale virkelighed og at serien som sådan kan ses som et dynamisk digitalt arkiv, hvilket især bliver tydeligt i den sidste uge af sæson 4.

Et centralt element til at opnå en effekt af intens indlevelse, er realtids-formidlingen, der betyder, at vi oplever historien som den sker i løbet af ugen, fordi en scene, som sker onsdag morgen offentliggøres på netop det tidspunkt. Der sker med realtids-formidlingen en sammensmeltning mellem vores almindeligt levede liv og seriens fiktive univers, hvilket endvidere underbygges af, at hele sæsonen ikke er færdigproduceret, når en ny sæson går i gang. Nyhedshistorier som fylder vores $\varnothing$ vrige nyhedsstrøm i den periode kan dermed indarbejdes $\mathrm{i}$ fortællingen (for eksempel valget af Donald Trump, klovneangreb eller HBO serien Westworld's sæsonafslutning i sæson 3). Det får den effekt, at i de 10-12 uger en sæson varer, "ser" vi ikke bare serien, vi lever i serien. Det er netop denne oplevelse af nærhed og virkelighed, som medieforsker Anne Jerslev undersøger i forhold til tværmedialiteten og realtids-oplevelsen. Hendes læsning af serien er centreret omkring spørgsmålet om, hvordan SKAM skaber en fornemmelse af nærvær forstået som et $n u$ i tid og et her i sted, og hun undersøger derfor SKAMs karakter af (medie)begivenhed, samt hvordan den digitale tværmedialitet og brugen af nærbilledet skaber et rum, som vi inviteres ind i og karakterer, vi kommer tæt på. Det er netop denne individuelle og intime 
oplevelse af SKAM, som baner vejen for en opbygning af et fællesskab, som serien også faciliterer og som en række af vores bidrag ser nærmere på i forhold til receptionen af SKAM og dens institutionelle forankring.

\section{Institutionelle og receptionsmæssige perspektiver. Offentlige og følsomme samtaler}

Seriens institutionelle forankring er Norges public servicekanal NRK. På sin vis skriver SKAM, med sin fortælling om individets forbundethed til kollektivet, sig ind $\mathrm{i}$ en klassisk public servicediskurs. De ovenfor nævnte eksempler på Nordic noir-serier som Creeber (2015) argumenterer for har en morale om kærligheden og fællesskabets frelsende kraft, er typisk også produceret som public service-indhold. I Nanna Kann-Rasmussen og Gitte Ballings artikel vises det, hvordan et kulturpolitisk perspektiv bidrager til forståelsen af SKAM's succes. Forfatterne trækker to forhold frem. Dels argumenterer de for, at SKAM leverer en moderne nordisk referenceramme for sin målgruppe (serien viser sit publikum, hvordan man kan agere tolerant, inkluderende og cool i livets svære situationer). Men ligeså vigtigt for forståelsen af SKAM som en public service-succes, er SKAMs evne til at skabe fællesskaber og offentlig samtale. En del af denne offentlige samtale foregår $\mathrm{i}$ de store fanfællesskaber som er temaet for flere af tidsskriftets artikler. På NRK's SKAM-blog diskuterer fans i et redigeret kommentarspor. Sidel øbende hermed har SKAM-fans selv skabt mange store og aktive online-fællesskaber. Her har fans i alle aldre, $k \varnothing n$ og nationaliteter, mens serien første gang blev offentliggjort, diskuteret serien i detaljer, delt oplevelsen af serien med hinanden og produceret memes, merchandise, fansubs, og teorier om seriens plotudvikling. Oplevelsen af at se SKAM var for mange fans meget mere end blot at følge med på bloggen eller at se fredagens episoder. Som ovenfor nævnt har det at følge med i SKAM betydet en intens følelse af nærvær. Seriens skiftende protagonister inviterede ikke blot seerne med ind i deres verden, de trådte ind i seernes. Det gjorde de fordi fortællingens dele, udvekslinger og diskussioner mellem Eva, Noora, Isak, Sana og de andre fandtes i de samme feeds, på de samme platforme som alle vores andre nyheder og beskeder befandt sig på. Det oplevedes simpelthen live.

Denne særlige liveness behandles $\mathrm{i}$ artiklen af Lone Kofoed Hansen og Stine Liv Johansen. De to forfattere diskuterer hvordan man, som forsker $\mathrm{i}$ online fanfællesskaber, altid er på arbejde og peger på metodiske udfordringer. Når hvert afsnit og den efterfølgende diskussion på fx Kosegruppa DK, med Jerslevs begreb bliver en begivenhed, må alt andet vige når "der er klip". Som forskere blev de to forfattere også fans, og artiklens bidrag er vigtigt, hvis man som ovenfor beskrevet mener, at SKAM er en game changer i forhold til transmedielle TV-serier og fankultur. Ida Hartmann Rasmussen og Bjarki Valtysson er også optagede af SKAMs fans. Gennem systematiske læsninger af kommentarer på SKAM-bloggen $i$ en enkelt sæson kombineret med fokusgruppeinterview fokuserer de på den afhængighed af serien og hungren efter mere SKAM som fansene har følt undervejs (som Veel benævner det rekonfigurerede narrative begær). Forfatterne viser hvordan seriens tværmedielle storytelling og network publics ikke blot producerede teorier og diskussioner om seriens indhold på bloggen, men i høj grad understøttede kommunikationen om fansenes egne følelser, identifikation og oplevelse af afhængighed af serien.

SKAMs fans har været bemærkelsesværdige på flere måder. Ud over den interne plotspecifikke og følelsesmæssige udveksling der har foregået i fanfællesskabernes egne fora, har SKAM i sidste halvdel af 2016 og første halvdel af 2017 fyldt meget i medierne. Seriens tematikker, fx vedrørende anoreksi, religion, homoseksualitet og psykisk sygdom er blevet debatteret i massemedier over hele Norden. Men også rettighedshaverens brug af geoblokering for udenlandske seere i januar 2017 har aff $\varnothing \mathrm{dt}$ heftig debat. Sebastian Schwemer viser i sin artikel, at SKAM har afdækket og aktualiseret presserende problemstillinger i forhold til det juridiske begreb grænseoverskridende adgang. Ligeledes diskuterer han, hvordan den transnationale reception af SKAM kan være begyndelsen til en ny balance mellem hensynet til rettighedshavere ( $\mathrm{x}$ af musikken) og forbrugere. Schwemers artikel afsluttes med en refleksion over, hvordan internettet som kulturel distributionskanal må rykke ved vores forestillinger om, hvem der skal have adgang til hvad. De traditionelle skel mellem producenter og forbrugere forskyder sig. SKAM som netdrama rykker således både ved de traditionelle kulturpolitiske forestillinger om adgang, men som især sæson 4 viste, også ved opdelingen mellem værk og fanfiction. I første episode af sæson 4 ankommer Sana til Isaks flyttelæs. De fem drenge, Even, Mahdi, Magnus, Jonas og Isak taler med Sana foran flyttebilen i en opstilling som en fan mellem sæson 3 og sæson 4 har tegnet 
(Woicik, 2017). Også i slutningen af sæson 4 blev mange fan-fantasier "realiseret", fx Williams tilbagekomst og genforening med Noora og langsomme close-ups af Penetrator Chris i bar overkrop. Serien har således institutionaliseret fans som medproducenter. Det kommer vi sandsynligvis også til at opleve i fremtidige TVserier.

\section{Hvad så?}

Indledningsvist stillede vi spørgsmålet om, hvordan man kan forholde sig til noget som i dén grad har en så markant situeret og tidslig komponent og hvor interaktionen med publikum på tværs af medieplatforme har været et afgørende element i den samlede oplevelse? Artiklerne i dette temanummer er skrevet, mens sæson 4 stadig blev vist. De behandler derfor serien og dens reception, som den forelå mens det hele var i gang. Men hvad med seriens efterliv? Hvad sker der med fællesskaberne, følelserne og optagetheden af seriens temaer og karakterer? Hvordan bevares de som forskningsobjekter? Og hvad sker der, når besættelsen har lagt sig og vi streamer serien i afsnit som så mange andre serier? Vil den så udmærke sig som andet og mere end endnu en god ungdomsserie? Hvilke nuancer vil stå frem, når vi får den affektive oplevelse af serien på afstand - på samme måde som når hjertesorgen over en abrupt afsluttet forelskelse gør os bedre i stand til at se forholdets fejl og mangler og ikke blot føle forførelsen? De kritiske røster har allerede meldt sig og blandt andet påpeget den måde, hvorpå Noora-William-historien gennemspiller kønsstereotype forestillinger og indirekte kan ses som en legitimering af en voldtægtskultur, hvor en kvindes nej ikke tages alvorligt (Nilsson 2016). Ligeledes har der været rejst kritik af, hvordan en serie som ellers berømmes for at give stemme og fabulationsrum til figurer som ofte er marginaliserede og stereotype i populærkulturen, så som den homoseksuelle, den manio-depressive og den muslimske kvinde, fastholder Jente-Chris i rollen som den typecastede tykke og sjove pige (Rud 2017). Seriens situering blandt velstillede 'hvide' norske unge uden nogen form økonomiske kvaler kan også diskuteres. Og endelig kan alliancen mellem public service-kanalers brug af kommercielle medier som Instagram og YouTube problematiseres. Aveny T's opsætning af teaterversionen af SKAM og American Idol-producenten Simon Fuller's annoncerede amerikanske re-make af serien er også en del af efter-bearbejdelsen af SKAM, som vil bidrage til at forme fremtidige læsninger af fænomenet. Vores håb med dette temanummer er gennem en tværvidenskabelig prisme at bidrage til at pege på den vifte af aktuelle problematikker, som serien peger ind i og er en del af. Seriens centrale udsigelse om relationen mellem det individuelle og det kollektive, som vi mener at kunne spore på et tematiske såvel som et formmæssigt og et receptionsmæssigt niveau, har vi hermed forsøgt at gøre til et forskningsmæssigt omdrejningspunkt, og ved hjælp af sammenstillingen af 14 forskellige perspektiver tilbyde vores læser et prisme til det videre arbejde med serien.

\section{Referencer}

Creeber, G. (2015). Killing us softly: Investigating the aesthetics, philosophy and influence of Nordic Noir television. Journal of Popular Television, 3(1), 21-35.

Kann-Rasmussen, N., Quist, P., \& Veel, K. (forthc.). From the Inside Out: Collective Perspectives on the Sensation of SKAM. I R. McCulloch, \& W. Proctor (Red.), The Scandinavian Invasion: The Nordic Noir Phenomenon and Beyond. Peter Lang.

Nilsson, M. (2016). Nej, William och Noora i SKAM är inte ett "gulligt" par. I Nyheter24 9.12.2016

https://nyheter24.se/nyheter/kronikor/870300-nej-william-och-noora-i-SKAM-ar-inte-ett-gulligt-par

Rud, I. (2017) SKAM fastholder tyk kliche. I Filmmagasinet Ekko 4.7.2017,

http://www.ekkofilm.dk/artikler/SKAM-fastholder-tyk-kliche/

Woicik, J. (2017). Gennem inkludering af fan-art cementerer Julie Andem 'SKAM's online-bevidsthed. I Soundvenue 11.4.2017. http://soundvenue.com/film/2017/04/gennem-inkludering-af-fan-art-cementererjulie-andem-SKAMs-online-bevidsthed-251196 